\title{
Banking Sector Problems: Causes, resolutions and consequences
}

\section{Jankov, Ljubinko}

Source / Izvornik: Occasional Paper Series, 2000, 4, 1 - 25

Journal article, Published version

Rad u časopisu, Objavljena verzija rada (izdavačev PDF)

https://doi.org/10.3326/ops.10

Permanent link / Trajna poveznica: https://urn.nsk.hr/urn:nbn:hr:242:837299

Rights / Prava: Attribution-NonCommercial-NoDerivatives 4.0 International/ImenovanjeNekomercijalno-Bez prerada 4.0 međunarodna

Download date / Datum preuzimanja: 2023-04-26

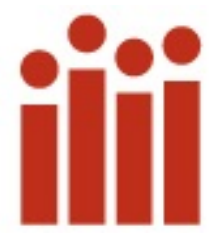

Institute of Public Finance Repository

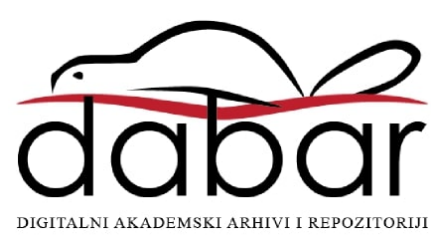


BANKING SECTOR PROBLEMS: CAUSES, RESOLUTIONS AND CONSEQUENCES

\author{
Ljubinko Jankov
}

Occasional Paper No. 10

March 2000

\author{
Institute of Public Finance \\ Katančićeva 5, 10000 Zagreb \\ CROATIA \\ tel: +38514819363 \\ fax: +38514819365 \\ e-mail: office@ijf.hr \\ (C) Institute of Public Finance 2000
}




\title{
BANKING SECTOR PROBLEMS: CAUSES, RESOLUTIONS AND CONSEQUENCES
}

\author{
Ljubinko Jankov
}

\begin{abstract}
Until the mid 1980s, commercial banking was the main lever of soft budgetary constraint. Commercial banks were under the control of their founding enterprises and their basic function was to approve the cheapest possible credit to their founders. The process of reforming commercial banking began during the last ten to twelve years. Since then, new laws and other regulations have been passed that are suitable for a market economy. In late 1991, a so-called linear rehabilitation of the banks began in which the majority of bad credits by banks were written off. The linear rehabilitation of the banks did not contain measures that would lead to changes in bank operations. Banks continued to approve credit to "their" enterprises. Therefore, in 1996 the government was forced to rehabilitate three large banks. These rehabilitations were conducted in a serious manner and were based on the transfer of bad bank credits to a special agency, recapitalization, replacing shareholders and replacing bank management. After these rehabilitations, there was a large drop in the interest rate. In 1998, there was a new bank crisis that chiefly affected new banks, which had highly aggressive interest rate policies. The fundamental cause of the new bank crisis was the inappropriate credit policies of these banks, exacerbated by various external shocks. The central bank began to intervene very quickly but only after the bank crisis occurred. Although many banks failed, it is not possible to speak about the end of the banking crisis. There are still many internal weaknesses in bank operations entwined with currency and credit risks, bank investment in enterprise shares, the maturity-gapping of assets and liabilities and the discrepancy between the information about banks and the possibilities for complying with regulations. These internal bank weaknesses open the possibility for similar banking problems in the future, which should be eliminated on time. The fiscal expenditures incurred to date for the rehabilitation of banks can be estimated in the amount of 31 percent of GDP, placing Croatian among the countries with the highest expenditures for bank rehabilitation.
\end{abstract}




\section{BANKING SECTOR PROBLEMS: CAUSES, RESOLUTIONS AND CONSEQUENCES'}

\section{Introduction}

Banking sector problems and bank failures have characterized recent financial trends in Croatia, as in many other transition countries. The costs of the financial rehabilitation of banks and the paying out of insured savings deposits are "dizzying" and place Croatia among the countries with the highest expenditures for solving bank problems.

This work analyzes the causes and measures for solving the banking crisis in Croatia. The second section summarizes the typical causes, consequences and resolutions of banking crises. The third section analyzes the methods and outcomes of resolving bank problems in Croatia during the period from 1991 to 1996. The fourth section is devoted to the bank crisis that occurred in 1998. The fifth section shows the total fiscal costs incurred to date to solve the bank problems in Croatia while the sixth and seventh sections demonstrate that the bank crisis is not over and additional steps are necessary to solve the banking problems.

\section{Basic Causes, Consequences and Resolutions of Banking Crises}

A bank becomes insolvent when its total liabilities, minus capital, become greater than its good or recoverable assets. The cause of insolvency is poor risk assessment in bank operations (credit risk, currency risk etc.) that results in the creation of bad or irrecoverable bank assets.

When insolvency occurs, assuming that other conditions remain unchanged, it results in bank losses and bank illiquidity. An insolvent bank must raise its interest spread in order to make a profit and remain liquid. An increase in the interest spread can occur under the following circumstances: (1) when there is no genuine competition on the bank market or (2) when several banks have the same problem (e.g. during the descending phase of an economic cycle).

An insolvent bank generally confronts the following choice: (1) to stop or (2) to continue providing credit to bad clients. By choosing the first option, the bank insures that will not create

\footnotetext{
${ }^{1}$ The opinions presented in this work are the author's and in no way reflect the position of the Croatian National Bank where the author is employed.

The Croatian version of this article was published in the journal "Financijska praksa" Volume 23, Number 6, (December 2000), and in Pregledi, Croatian National Bank, Number P-2, (January 2000).

${ }^{2} \mathrm{~A}$ lesser problem than insolvency is inadequate bank capital. In this instance, the bank liabilities are fully backed by good assets, but the rate of return on capital is lower than customary on the market.
} 
new losses and actually acknowledges the problem of bad assets. By choosing the second, the bank assumes the risk of new losses and assumes that new loans to the same client will enable that client to settle in an orderly manner all his obligations in the future. In order to implement the second option, additional funds will be necessary in order for the bank to remain liquid. Additional funds are easiest to raise by increasing deposit interest rates. The client will pay interest on his old loans with the new loans and the bank will continue to make a profit. However, if the client remains bad, the problem of bad assets will reoccur in even greater magnitude. In such a case, bank insolvency will occur significantly earlier than illiquidity or losses in bank operations.

Confidence plays a key role in bank operations. Any information whatsoever implying that the financial position of a bank has worsened can have a negative impact on all the cash flow in that bank. Therefore, every bank will attempt to conceal the problem of insolvency. Banks are highly successful in this respect and, therefore, the problem of insolvency is often not recognized in time by the government agencies entrusted with bank supervision.

Problems in the banking system or in the economy as a whole occur when a number of banks become insolvent, or when a relatively large share of the liabilities of the banking system is not covered by good assets. The occurrence of such problems indicates that the inefficient asset and liability management is present in a significant portion of banking. If a large part of banks' assets are allocated to unprofitable projects, there will be a reduction in investment efficiency and thereby a slowdown in economic growth.

Problems in the economy as a whole are usually further exacerbated when the problems of bank insolvency begin to be resolved. When banks attempt to restore solvency by ceasing to grant loans to bad clients and raising the interest spreads, there is less available loan and they are more expensive. One consequence can be the negative selection of clients. Enterprises that do not have alternative sources of financing will be ready to accept higher bank interest rates, independently of whether the projects to be financed are profitable or less profitable. Such a trend will also exert a negative impact upon investment efficiency and economic growth.

If banks attempt to solve the problem of insolvency by raising additional funds, interest rates will rise and there will be pressure to conduct a softer monetary policy. Banks can also seek additional liquidity in foreign countries, which affects the trends in the balance of payments. The problem of bank insolvency can be solved by the financial rehabilitation of the banks. ${ }^{\text {B }}$ Financial rehabilitation will generally result in lower interest spreads and interest rates, and it will

\footnotetext{
${ }^{3}$ There are various ways to rehabilitate banks financially: recapitalization of a bank or its clients, mergers with other banks etc.
} 
solve the problem of the negative selection of clients if the old bank management is replaced. However, financial rehabilitation always includes significant fiscal expenditures and has the effect of increasing the fiscal deficit, which can undermine total macroeconomic stability. Financial rehabilitation also signifies an explicit or implicit government guarantee to cover all the obligations of the problem bank. If financial rehabilitation creates the expectation that the government will rehabilitate every problem bank, the depositors will become insensitive to the quality of banking business and will invest in high-risk banks that offer higher deposit interest rates than other banks.

The bankruptcy of insolvent banks results in a (partial) loss of the depositors' assets. If the depositors of a bank in bankruptcy cannot meet their obligations toward others due to the loss of their property, this leads to a chain of losses and bankruptcies. Such chain reactions are very difficult to foresee in advance. They are more likely in the bankruptcy of a large bank or a bank with heavy interbank liabilities. Experience shows that the bankruptcy of one bank is usually followed by the bankruptcies of other banks. The decision to have a bank declare bankruptcy will be easier to make if there is an efficient system for insuring deposits, which guarantees that small depositors (depositors with small deposits) of banks in bankruptcy will get their money back. Small depositors usually do not possess adequate information on bank operations and cannot differentiate good banks from bad. Therefore, they react to reports of bankruptcy by beginning to withdraw their deposits from all banks. If large payouts are in question, the problem of liquidity can also occur in good banks. This problem will not be serious, if the central bank reacts quickly as a lender of the last resort.

\section{Resolutions of Bank Insolvency Problem in Croatia during the Period from 1991 to 1996}

\subsection{Linear Rehabilitation of Banks}

Although a two-tier banking system has existed in Croatia for several decades, in which the functions of the central bank are separate from the functions of the commercial banks, the genuine reform of commercial banking only began 10 to 12 years ago. Until the mid 1980s, commercial banking was the main lever of soft budgetary constraint. Commercial banks were under the control of their founding enterprises, and their basic function was to approve the cheapest possible credit to their founders.

The monetary policy and institutional environment facilitated the nonprofitable behavior of the banks. The basic instruments of monetary policy were the so-called central bank selective loans 
and setting of ceilings on banks' loans. Selective loans in essence made it possible for banks to become limitlessly indebted to the central bank - and this at very low and generally negative interest rates. Under these conditions, the central bank did not have control over the monetary base and was forced to limit banks' credits in order to control the money supply. The institutional environment created operating conditions in which the competition among banks was exceptionally low. The low level of competition among banks was particularly favored by: (1) cartel ("self-management") bank agreements regarding the level of the interest rates on household deposits and (2) the rule that an enterprise could hold only one giro account with banks. Since the deposits in the giro accounts of banks are the cheapest source of funds, all the banks stipulated in their credit policies that an enterprise had to have its giro account at the bank from which it sought credit. Consequently, the enterprises transferred their transactional balances from one bank to another only if they expected that the second bank would approve cheaper credit than the first.

Starting in the mid 1980s, a gradual reform in the banking system began, with changes in the law and other regulations. Banks were transformed into joint stock companies or similar types of enterprises. The former founding enterprises became the stockholders of the transformed banks, whose decisions were no longer issued according to the principle of "one founder - one vote" but depended on the extent of owners' equity concerning banking supervision, such as a limit on lending the individual borrower, the adequacy of capital, the assessment of credit risk and the formation of specific reserves for bad credits. The actual indebtedness of the bank owners (stockholders) generally exceeded the stipulated lending limits, and adjustment to the limits had to be implemented during the transition period. Supervision of bank operations and the enforcement of these regulations were entrusted to the central bank. This was an exceptionally difficult task considering that the bank owners had opposing interests.

In the area of interest rates, the policy of real negative interest rates was discontinued, particularly after the introduction of mandatory indexing according to inflation, which was applied for two years. There was an end to cartel agreements regulating interest rates on household deposits, which increased competition among the banks, particularly in the area of collecting household foreign currency deposits. By collecting these deposits, the banks obtained the foreign currency needed to finance imports by the bank owners' enterprises, and consequently accumulated a short foreign currency position. Adjusting the monetary policy to the new conditions was slower than

\footnotetext{
${ }^{4}$ Later ownership transformations of older banks depended primarily on the course of the transformation and privatization of the stockholding enterprises.

${ }^{5}$ The establishment of new banks should have also contributed to increased competition among banks. Therefore, the new regulations established relatively liberal conditions for the establishment of new banks.
} 
changing the regulations. There were several attempts regarding the abolition and limitation of central bank selective loans, which were finally abolished in late 1993.

Considering that profitability and risk analysis were not the basic parameters for the bank credit policies, bad bank credits were more the rule than the exception. High inflation greatly contributed to the resolution of the problem of bad credits, which brought the banks capital profit by reducing the real value of the bad credits and by reducing the real value of the liabilities on the basis of deposits in domestic currency. Liabilities that ensued from household foreign currency deposits could not be devalued by inflation and resulted in great losses to the banks, so that even the former Yugoslavia acknowledged them as its public debt.

Despite high inflation and the newly formed public debt, there remained large uncovered bank losses. The auditing firm of Coopers \& Lybrand, in collaboration with the Public Accounting Service, prepared an analysis of the quality of the assets of the banks according to data from 1989. Their results showed that at that time the bad assets were twice the size of the bank capital. On the basis of their results and its own inquiries, the Croatian National Bank noted the following in its 1991 Annual Report: “At the end of 1990 ... five banks were solvent, ten banks were solvent with problems in connection with the settlement of claims, eleven banks were technically insolvent and two banks were seriously technically insolvent." Accordingly, at that time the problem of insolvency was present in 13 out of a total of 28 banks.

In the analysis provided by the auditing firm of Coopers \& Lybrand, claims which were later transformed into bonds of the Republic of Croatia on the basis of old foreign currency savings accounts were entered as the highest quality bank assets. They concerned claims upon the former National Bank of Yugoslavia, which comprised approximately 50 percent of the total bank assets. With the dissolution of the former Yugoslavia, the National Bank of Yugoslavia stopped settling these claims and they became worthless. The problem of insolvency drastically increased and probably occurred in all the banks.

The problem of old foreign currency savings had to be solved rapidly in order for the banks to conduct at least somewhat normal operations. That is what happened. In late 1991, the decision was made to issue bonds on the basis of old foreign currency savings accounts and to block household foreign currency accounts. ${ }^{\square}$ By this decision, the public debt of the former Socialist

\footnotetext{
${ }^{6}$ Capital gains saved Međimurska Banka, Čakovec. In the late 1980s, the losses of that bank exceeded its capital many times over. The government institutions deliberated upon how to rehabilitate that bank for a long time. In the end, reorganization was not necessary because the real values of the losses simply "melted."

${ }^{7}$ Bonds for old foreign currency savings accounts are all the bonds and claims on the Republic of Croatia that are counter entries for blocked household foreign currency savings accounts. The Republic of Croatia blocked household foreign currency savings accounts for a certain period because it did not have
} 
Federal Republic of Yugoslavia was recognized as a public debt by the Republic of Croatia. The operations of exchanging claims and blocking deposits were only relatively reliably reflected by the bank records in June 1992. At that time, the bonds comprised 44.7 percent of the assets of the banks and the blocked deposits comprised 41.5 percent of the liabilities of the banks. ${ }^{1}$ The operation itself had a neutral effect on the quality of the bank assets. This form of asset continues to be considered as the highest quality asset.

In order to solve the problem of bank insolvency that was recorded in the auditing reports, in 1991 and 1992 the government issued so-called "big bonds. ${ }^{1}$ The bonds were mainly received by the final users of central bank selective loans, i.e. agricultural conglomerates, shipbuilding enterprises and enterprises oriented to the former Soviet Union and Eastern Europe market, who thereby paid their obligations to banks. This involved large government-owned enterprises, i.e. the clients of large banks. Quite unexpectedly, the operation "completely" solved the problem of bad banks. In the 1991 Annual Report of the Croatian National Bank, the following was recorded: "In 1991 ... there was a surprising growth of capital, at an average of 225 percent ... by which the coefficient of the capital adequacy was increased in the fourth quarter from 1.6 percent to 14.8 percent .... The causes of this, first of all, are in the entered revaluation of the bonds of the Republic of Croatia. On the basis of these bonds, contaminated assets are removed and thereby potential losses are reduced. The revaluation was performed according to the growth rate of industrial prices, entered as revenues according to the final accounting statement of the banks, that are directed toward long-term reserves and enlarging the founders' capital." "Good" financial results by the banks were achieved owing to high inflation and the failure to enter all the costs. In 1991, producer prices rose by 122.4 percent, which was the basis for the revaluation of the "big bonds." Banks did not enter the enormous costs that were incurred due to the changes in the rate of exchange. They had a large short foreign currency position. The official rate of exchange according to which the foreign currency items were shown in the financial statement was 13 units of the domestic currency per Deutsch mark, while at the same time the market rate of exchange was 37 units of the domestic currency per Deutsch mark.

international reserves. The bonds bear 5 percent interest, payable semiannually and indexed according the German mark.

${ }^{8}$ The original claims were equal to the deposits. However, in 1991 the banks paid off the deposits, but they could not recover their claims for these deposits.

${ }^{9}$ The government issued "big bonds" in 1991 and 1992 for certain enterprises on the basis of a 1991 law. With these bonds, the enterprises repaid banks the nominal value of their overdue obligations. These bonds were issued for a term of 20 years, indexed to the producer price index and formally earned 5 percent interest annually, payable semiannually. However, later the Ministry of Finance additionally explained that these bonds were actually without interest because the semiannual payment of interest was actually repaying the principal. 
"Big bonds" fundamentally altered the financial indicators of bank operations. Their issue on one hand formally solved the problem of insolvency, and on the other hand, the customary rehabilitation measures were not implemented, such as changes in management and bank ownership, prevention of granting further credit to bad debtors, reduction of the operating expenses, forming special units for repayment of bad loans etc. Since such measures were not undertaken, significant changes did not occur in banking operations. The banks that had previously been bad continued to operate badly. Therefore, the issue of the "big bonds" together with the issue of bonds on the basis of old foreign currency savings accounts is most often referred to as linear bank rehabilitation.

The measures of linear bank rehabilitation also had a great positive impact. Recognition of old foreign currency savings accounts as a government debt restored confidence in the banks. During 1990 and 1991, a large part of foreign savings was withdrawn and transferred to foreign banks or hoarded. Despite the blocking of the remaining foreign currency savings accounts in late 1991, during the following two years there was a gradual return of foreign currency savings accounts to domestic banks.

\subsection{The Rehabilitation of Three Large Banks in 1996}

The inefficiency of bank operations was publicly acknowledged in 1996 when the government rehabilitated three out of the four largest banks. ${ }^{-}$For every bank, a special decision was published in the official government gazette that described its rehabilitation.

The rehabilitation of these banks was primarily a consequence of their bad operations in the period from 1991 to 1996 . The banks recorded losses that were several times greater than their capital, and that were the consequence of new irrecoverable credits to large government enterprises. During rehabilitation, it was assessed that in these three banks there was a very great volume of bad credits, i.e. that the banks were insolvent. Splitska Banka, Split had 2.3 times more bad credits than capital, Riječka Banka, Rijeka had 1.4 times more and Privredna Banka, Zagreb approximately 2.7 times more. ${ }^{2}$ The share of bad credit in the total bank's credits was 16.3 percent in Splitska Banka, Split and 29.9 percent in Riječka Banka, Rijeka, while for

\footnotetext{
${ }^{10}$ However, the problem of bank liquidity remained. The government did not settle its claims on time or in cash. Claims on the government were unmarketable, because they were not negotiable.

${ }^{11}$ In 1995, rehabilitation for one additional medium-sized bank was performed. There is not much publicly accessible data on this rehabilitation.

${ }^{12}$ Precise data were not published for Privredna Banka, Zagreb. The estimated amount includes credits written off by debiting capital and reserves and credits transferred to the Agency, but it does not include credits that were fully provisioned by the bank.
} 
Komercijalna Banka, Zagreb that share was not published but was probably the largest. $\frac{1}{3}$ From the standpoint of the banking system as a whole, the rehabilitation of Privredna Banka, Zagreb was more significant than the rehabilitation of Splitska Banka, Split and Riječka Banka, Rijeka. Immediately prior to the rehabilitation of that bank, the share of its bad credits within the total credits of all the banks to domestic enterprises was 25.1 percent.

Table 1. Bad credits in three rehabilitated banks, in million kuna

\begin{tabular}{|c|c|c|c|c|c|}
\hline & $\begin{array}{l}\text { Total } \\
\text { bad } \\
\text { credits }\end{array}$ & $\begin{array}{l}\text { In this: bad } \\
\text { credits } \\
\text { transferred to } \\
\text { the Agency }\end{array}$ & $\begin{array}{l}\text { Total bad } \\
\text { credits as a } \\
\text { percent of } \\
\text { the bank } \\
\text { capital }\end{array}$ & $\begin{array}{c}\text { Total bad } \\
\text { credits as a } \\
\text { percent of the } \\
\text { total credits of } \\
\text { the bank }\end{array}$ & $\begin{array}{l}\text { Total bad } \\
\text { credits as a } \\
\text { percent of the } \\
\text { total credits of } \\
\text { all banks }\end{array}$ \\
\hline Splitska Banka, Split & 799 & 454 & $231.6 \%$ & $16.3 \%$ & $2.7 \% * *$ \\
\hline Riječka Banka, Rijeka & 829 & 246 & $142.2 \%$ & $29.9 \%$ & $2.8 \% * *$ \\
\hline Privredna Banka, Zagreb & 7,920 & $4,559 *$ & $267.9 \%$ & no data & $25.1 \% * * *$ \\
\hline Another $\mathrm{H}$ & \multicolumn{5}{|c|}{ Another HRK 1,785 million transferred to the Agency as written-off claims } \\
\hline In compar & \multicolumn{5}{|c|}{ In comparsion to the credits to enterprises at the end of July 1996} \\
\hline In compar & \multicolumn{5}{|c|}{ In comparison to credits to enterprises at the end of November 1996} \\
\hline
\end{tabular}

Sources: Bulletin of the Croatian National Bank

Official Gazette of the Republic of Croatia

In all three banks, there was an exceptionally high concentration of bad credits. Over 90 percent of the bad credits were granted to several large enterprises under government ownership. Later, the government undertook a special rehabilitation process for some of the enterprises.

All three rehabilitation processes were characterized by the following:

a) Transfer of bad credits to a special agency

In all three rehabilitation processes, one part of the bad credits was transferred to a special agency (55 percent of the total bad credits of these three banks) and the others were written off by debiting the bank capital and reserves (45 percent of the total bad credits of these three banks). Decisions for the rehabilitation of banks do not include the forgiveness or rescheduling of the

${ }^{13}$ For Privredna Banka, Zagreb, a slightly unusual procedure for reconstructing the balance was employed. First, from the original balance sheet were removed the liabilities arising from the foreign borrowings that the bank took in its own name and for the accounts of its clients, as well as the counterpart bank claims against clients. Then some other credits to customers were also removed and the balance sheet value of the claims on the central government was increased by the amount "agreed with the bank". The standard analysis of quality of the banks' assets started only after such reorganization.

${ }^{14}$ The State Agency for Deposit Insurance and Bank Rehabilitation. 
liabilities of bad debtors. Their obligations should fall due as originally negotiated. However, the debts of some debtors were restructured (practically forgiven) by the direct rehabilitation of the enterprises.

\section{b) Recapitalization}

After the write-off of bad credits, the government recapitalized each bank to the level of the minimal capital adequacy. In all three banks, this procedure downsized the total assets. For example, Privredna Banka, Zagreb was the largest bank in Croatia prior to rehabilitation and following rehabilitation it became the second largest bank.

\section{c) Changes in Bank Shareholders}

The old shares, whose owners were government-owned enterprises, were invalidated. The Agency became the new bank shareholder. The government immediately announced that it would privatize rehabilitated banks, which has still not occurred. However, preparations for privatization began in earnest in early 1999 through the engagement of foreign advisers for privatization.

\section{d) Changes in Bank Management}

The old bank management was replaced. Special trustees were appointed who were responsible to the Agency for their work. The new management began to introduce changes in the operations and organization of the rehabilitated banks in cooperation with auditors and foreign experts.

The most obvious consequence of the rehabilitation of the three large banks was a decline in lending rates. The interest rates on short-term credit suddenly fell, immediately following the rehabilitation of Splitska Banka, Split and Riječka Banka, Rijeka and remained at approximately the same level until the second quarter of 1998. The decline in the interest rate on long-term credit was significantly less and slower, but the downward trend of these interest rates continues until today.

The trends in the interest rates for short-term credit represent the interest rates on the money market. These interest rates fell from $26.3 \%$ in the second quarter to $11.4 \%$ in the third quarter of 1996. After this one-time adjustment, a general decline continues in these interest rates, which in the fourth quarter of 1997 reached the level of $8.9 \%$. In 1998, there was a change in the trend, i.e.

\footnotetext{
15 The transfer of only a part of the bad credits to the Agency is an unusual solution. The criteria for the distribution of the credits between the Agency and banks were not published.
} 
a rise in the interest rates on short-term credit, which occurred at the same time as the new banking crisis.

Trends of interest rates for long-term credit represent the interest rates on credits in kuna indexed to foreign currency. With these interest rates, there was not a one-time adjustment, but after the rehabilitation of the three banks the interest rates on long-term credit have fallen continuously but gradually. It is interesting that this trend did not change in 1998.

Table 2. Average Quarterly Interest Rates of Banks ${ }^{16}$, on annual basis and in percentage

\begin{tabular}{|l|c|c|c|c|c|}
\hline Year & Quarter & $\begin{array}{l}\text { Daily money } \\
\text { market }\end{array}$ & $\begin{array}{l}\text { Credits in kuna } \\
\text { indexed to } \\
\text { foreign } \\
\text { currency }\end{array}$ & $\begin{array}{l}\text { Time } \\
\text { deposits } \\
\text { in kuna }\end{array}$ & $\begin{array}{l}\text { Foreign } \\
\text { currency time } \\
\text { deposits }\end{array}$ \\
\hline 1995 & 1 & 17.2 & 13.9 & 9.9 & no data \\
\hline & 2 & 19.1 & 20.4 & 10.8 & no data \\
\hline & 3 & 23.0 & 23.8 & 11.4 & 6.6 \\
\hline & 4 & 25.2 & 22.4 & 13.0 & 6.5 \\
\hline 1996 & 1 & 29.7 & 24.3 & 15.0 & 6.8 \\
\hline & 2 & 26.3 & 22.9 & 14.6 & 6.5 \\
\hline & 3 & 11.4 & 21.4 & 12.7 & 6.5 \\
\hline & 4 & 10.0 & 19.9 & 10.3 & 7.6 \\
\hline 1997 & 1 & 11.4 & 18.6 & 9.9 & 6.4 \\
\hline & 2 & 11.3 & 16.3 & 9.9 & 6.1 \\
\hline & 3 & 9.3 & 15.6 & 9.4 & 5.9 \\
\hline & 4 & 8.9 & 15.3 & 8.9 & 6.1 \\
\hline 1998 & 1 & 10.1 & 15.3 & 9.0 & 7.2 \\
\hline & 2 & 16.0 & 15.0 & 9.7 & 7.4 \\
\hline & 3 & 16.0 & 14.5 & 9.7 & 6.6 \\
\hline & 4 & 15.8 & 13.7 & 8.7 & 5.4 \\
\hline
\end{tabular}

Source: Bulletin of the Croatian National Bank

The rehabilitation of the three large banks also had an impact on the decline in the interest rates on time deposits in kuna. The trend in these interest rates was equal to that of the trend in the interest rates on the money market. On the other side, the trend in the interest rates on foreign currency deposits was determined by other factors. The majority of Croatian banks traditionally pay interest on foreign currency deposits according to rates that are higher than paid in foreign countries for the same type of deposits, which is a result, primarily, of the policy of attracting foreign currency saving accounts, and only to a lesser extent the result of a risk premium.

\footnotetext{
${ }^{16}$ The interest rates are the arithmetic mean of the monthly interest rates published in the Bulletin of the Croatian National Bank.
} 
It is also useful to examine the trends in the interest rates prior to the rehabilitation of the three banks. In 1995, more rapid growth in the interest rates was recorded on the money market and on time deposits in kuna. The trends of these interest rates indicate that the three banks solved the problem of insolvency by gathering new deposits and debt accumulation on the money market.

\section{The New Banking Crisis of 1998}

The new banking crisis occurred following the end of the period of fast growth in bank credits, that began with the passage of the stabilization program in late 1993. The crisis occurred in a year of significantly increased fiscal revenues owing to the introduction of a value-added tax. The increased fiscal revenues drastically increased the consumption appetites of the government and led to a revision of the budget, by which the fiscal expenditures were increased. In late 1998, the government announced that a relatively small budget deficit had been achieved. However, this deficit was underestimated because it did not include many unsettled expenditures. The government included a part of these expenditures, in the form of bills of exchange to be honored, in budgetary expenditures for 1999. The bank crisis occurred simultaneously with a narrowing of foreign borrowing opportunities following the Asian and Russian crises. The reduced borrowing opportunities led to a reduction in the deficit of the current account of the balance of payments.

In early 1998, Dubrovačka Banka, Dubrovnik failed. In a very short time, only several months, the decision was made to rehabilitate this bank, based on the same model as the previous three individual rehabilitations. The crisis and rehabilitation of this bank were accompanied by a major political affair, which certainly contributed to the speed of the problem solving. However, the banking crisis and the political affair undermined confidence and resulted in a withdrawal of deposits from other banks which people assumed could be connected with the protagonists of the affair. The deposits in the banking system as a whole did not diminish but there was a significant redistribution of deposits among the banks.

Dubrovačka Banka, Dubrovnik was the fifth largest bank in Croatia when it stopped meeting its obligations in an orderly manner. In July 1998, the same was the case with the sixth bank in order of size. After that, in the fourth quarter of 1998 and early 1999, several more medium-sized and small banks stopped meeting their obligations. In contrast to Dubrovačka Banka, Dubrovnik there was not prompt rehabilitation of these banks. The banks practically stopped working. Their depositors - at least temporarily — were left without their property, which had a negative impact

17 The bank made considerable equity investments in Dubrovnik hotels, and certain people made a partnership contract that, probably, was in essence a plan for taking over the bank with the goal of taking over the hotels owned by the bank. Until now, all the signers of the contract have not been confirmed, because the original document was stolen. 
on aggregate demand. Among the bank depositors, there were also foreign creditors who experienced losses. The majority of the German banks made an agreement to stop issuing credit to Croatian banks. This stoppage of credit had the additional effect of reducing the deficit of the current account of the balance of payments in 1998.

The majority of the banks that stopped meeting their obligations in an orderly manner were new banks, established after 1991. These banks were also fast growing banks with aggressive interest rate policies. Babić, Jurković and Šonje (1999) note that in 1997 the central bank prepared a special report for the Parliament in which it was mentioned that there were eight banks of medium size with an aggressive interest rate policy. These eight aggressive banks calculated interest according to significantly higher lending and deposit rates than other banks. For example, in late 1996, these banks paid interest on savings and time deposits at an average interest rate of approximately 12 percent, while stable banks were paying interest at a rate of approximately 8 percent. Medium-sized banks can be defined as banks with total assets from HRK 1 to HRK 10 billion. In late 1993, there were six such banks in Croatia, and in late 1997 - when the central bank prepared its report - there were seventeen such banks. Accordingly, it can be concluded that eight of the eleven new banks of medium size based their growth on interest rates that were significantly higher than the interest rates of other banks.

Table 3. Number of banks and their classification by size, end of period

\begin{tabular}{|l|c|c|c|c|}
\hline Year & Number of banks & $\begin{array}{c}\text { Banks with total } \\
\text { assets less than 1 } \\
\text { billion kuna }\end{array}$ & $\begin{array}{c}\text { Banks with total } \\
\text { assets from 1 to } \\
10 \text { billion kuna }\end{array}$ & $\begin{array}{c}\text { Banks with total } \\
\text { assets of 10 billion } \\
\text { kuna or over }\end{array}$ \\
\hline 1993 & 43 & 35 & 6 & 2 \\
\hline 1994 & 50 & 40 & 8 & 2 \\
\hline 1995 & 53 & 42 & 9 & 2 \\
\hline 1996 & 57 & 42 & 13 & 2 \\
\hline 1997 & 60 & 41 & 17 & 2 \\
\hline 1998 & 60 & 37 & 21 & 2 \\
\hline
\end{tabular}

Source:

Bulletin of the Croatian National Bank

At the end of the first quarter of 1999, the central bank proposed initiating bankruptcy proceedings for the majority of the banks that were not meeting their obligations in an orderly manner with the explanation that their "losses are far greater than their capital" (public statement issued by the Croatian National Bank, March 24, 1999). In April 1999, the court instituted bankruptcy proceedings, and the government began to prepare a revision of the budget that included the paying out of insured savings deposits. 
The new banking crisis made it necessary for the central bank to provide prompt additional credit to the banks. There are two ways of providing additional central_bank loan to banks: (1) hidden financing, i.e. the creation of the administrative mechanism for transferring overnight funds from surplus to deficit banks and (2) short-term liquidity credits.

Hidden financing was introduced in the second quarter of 1998 when there was a sudden rise in the interest rates on the daily money market. The interest rate rose from 10.1 percent in the first quarter to 16.0 percent in the second quarter. Certain deficit banks with a shortage of free reserves were not able to borrow even at such a high interest rate. The majority of the banks decided not to participate in the money market at all, and the money market simply disintegrated. The central bank solved the problem of deficit banks by introducing a "change" in operations of the so-called overnight money market. The essence of this change is that the banks can approve overnight interbank credits without any credit risk whatsoever. 1.8 The overnight market was in effect abolished and replaced by an administrative mechanism for financing of deficit banks by debiting surplus banks. Deficits are covered without direct changes in the balance sheet of the central bank. However, the abolition of the administrative redistribution of the banks' deposits with the central bank would lead to a change in the balance of the Croatian National Bank, i.e. it would show either the_required reserve deficiencies of some banks, or larger central banks credits to the same banks.

The bank illiquidity can be financed administratively by approving overnight credits until the value of deficit in free bank's reserves is less than the value of bank's required reserves with the Croatian National Bank. However, in the case of larger deficits and after the required reserves are exhausted, only direct borrowing from the Croatian National Bank remains. In 1999, such measures occurred. A new form of the credit financing of banks was introduced by the central bank, which was intended for banks with the problem of liquidity. New credits, so-called shortterm liquidity credits, are approved on the basis of the collateral of government and private creditors' marketable debt securities and on the basis of measures for improving the liquidity that borrowing bank proposes. They are formally intended for solvent banks but it is an open question whether the banks that take them are actually solvent. These credits are one of the basic ways of creating primary money in the first five months of 1999.

In principle, not one of the mentioned two measures of the central bank should result in the creation of bad credits in the balance sheet of the central bank, that could result in the loss of

${ }^{18}$ A designated broker is given insight into the end-of-day position of all the banks and is authorized to permit overnight credits only if a debtor bank has cash in a separate required reserves account with the central bank. Such an overnight credit is repaid by debiting the required reserve account, and it results in the required reserve deficiency. 
government revenues or even direct fiscal expenditures if the government would have to cover the losses of the central bank. The administrative approval of overnight credit makes it possible for banks without liquidity to consume their own required reserves. Liquidity credits are insured with first-class guarantees. This, however, does not signify that in the financial statement of the central bank there are not bad credits. One of the monetary policy instruments is the so-called intervention credit, which is uninsured loan for required reserved deficiencies of a bank for a very brief period of one or two days. Such credit is approved automatically by crediting bank's required reserve account with the central bank up to the amount of required reserves. Intervention credit becomes bad credit in the following scenario:

1. The bank constantly uses overnight credit, i.e. gradually consumes its required reserves.

2. The bank illiquidity gradually becomes worse, and the value of deficit in free bank's reserves eventually exceeds the value of bank's required reserves. In this case, the bank stops using overnight credit and the Croatian National Bank automatically approves intervention credit up to the level of the required reserves and at the same time blocks bank's outgoing payments in order to collect it.

3. If the bank has lost the confidence of its clients, it cannot leave the blockade or return the intervention credit.

Such a scenario occurs in all banks in bankruptcy.

Recent trends during the new banking crisis show that the basic causes of the crisis are to be found in the aggressive and excessively risky credit policies of certain banks. It is equally clear that the central bank did not take serious measures in time to prevent the bank crisis but instead began to intervene rapidly only after the crisis occurred. The bank crisis was intensified by external shocks: lower foreign borrowing, a growth in fiscal expenditures and unsettled central government obligations, temporary or complete loss of deposits with problem banks and the disintegration of the interbank market.

\section{Fiscal Expenditures for the Rehabilitation of Banks in Croatia up to 1998}

The fiscal expenditures for the rehabilitation of banks are the expenditures of linear rehabilitation and individual rehabilitation. In the expenditures of linear rehabilitation are included the "big bonds," bonds arising from old foreign currency savings accounts and bonds issued for the payment of interest and the refinancing of bonds arising from old foreign currency saving 
accounts. 1 In the expenditures for individual rehabilitation are included the expenditures for the rehabilitation of Slavonska Banka, Osijek, Riječka Banka, Rijeka, Splitska Banka, Split, Privredna Banka, Zagreb and Dubrovačka Banka, Dubrovnik.

The total fiscal expenditures for the rehabilitation of banks in Croatia during the period from 1991 to 1998 can be estimated at approximately 31 percent of the annual gross domestic product (GDP). ${ }^{20}$ These expenditures occurred during the following periods:

1. In late 1991, the government issued bonds for the linear rehabilitation of banks in the amount of 22.6 percent of GDP (of which 5.6 percent concern "big bonds").

2. From 1993 to 1996, various bonds were issued for the payment of interest and the refinancing of bonds for old foreign currency savings accounts in the amount of 1.2 percent of GDP.

3. In 1996, various bonds were issued for the rehabilitation of Riječka Banka, Rijeka, Splitska Banka, Split and Privredna Banka, Zagreb in an amount of 6.1 percent of GDP (for the recapitalization of these banks bonds were issued in an amount of 2.5 percent of GDP, 21 and within the framework of the rehabilitation of Privredna Banka, Zagreb the government took over a part of the foreign debt of that bank in the amount of 3.6 percent of GDP).

4. In 1998, bonds were issued for the rehabilitation of Dubrovačka Banka, Dubrovnik in the amount of 0.8 percent of GDP. 22

Croatia is among the countries with the highest fiscal expenditures for the rehabilitation of banks. ${ }^{2}$ Dziobek and Pazarbasioglu have analyzed the largest banking crises during the period from 1981 to 1994. Twenty-four countries are included in this analysis, i.e. those countries in which over 20 percent of the deposits of their entire banking system were in problem banks. The following countries had the highest fiscal expenditures for the rehabilitation of banks in the period from 1981 to 1994 (in percentages of the annual GDP):

\footnotetext{
${ }^{19}$ In 1993 and 1994, the government did not pay interest on bonds arising from old foreign currency savings accounts in cash but by issuing new bonds. In 1995 and 1996, besides interest, the government also used new bonds to pay for the due principal of the bonds arising from for old foreign currency savings accounts.

${ }^{20}$ Calculated on the basis of data on GDP published by the State Bureau of Statistics.

${ }^{21}$ In this amount, the exchange of "big bonds" from 1991 for new "big bonds" is not included. In contrast to the former, the latter bear interest.

${ }^{22}$ All the fiscal expenditures for the rehabilitation of banks, except for the payment of interest through the issuing of bonds, are not shown as budgetary expenditures because the Ministry of Finance draws up the budget of the central government on the cash basis. The fiscal expenditures of the rehabilitation of banks are only included in statistics on the central government debt. The Ministry of Finance, sometimes in the same fiscal year, bought back part of the rehabilitation bonds prior to their maturity, and this is shown in the budget as debt repayment.

${ }^{23}$ In addition to fiscal expenditures, there are also other expenditures in the rehabilitation of banks. Significant expenses are usually borne by the private sector, whether through the loss of the shares of problem banks or due to the devaluation of the deposits under the conditions of inflation.
} 


$\begin{array}{lc}\text { Kuwait } & 45 \\ \text { Chile } & 33 \\ \text { Venezuela } & 17 \\ \text { Spain } & 15 \\ \text { Mexico } & 12-15 \\ \text { Hungary } & 12 \\ \text { Finland } & 10\end{array}$

The fiscal expenditures for the rehabilitation of banks are the main component of the debt of the central government. In late 1991, the government debt due to the rehabilitation of banks was 96.5 percent of the total government debt. This share was continuously reduced during the period from 1991 to 1998 and in 1998 reached 50.3 percent of GDP. The total government debt remained at a relatively low level. The share of the total debt in GDP grew from 23.4 percent in 1991 to 26.4 percent in 1998.

Table 4. Government debt due to the rehabilitation of banks, in million USD and in percentage

\begin{tabular}{|c|c|c|c|c|c|}
\hline & 1991 & 1995 & 1996 & 1997 & 1998 \\
\hline $\begin{array}{l}\text { 1. Domestic debt of the central } \\
\text { government }\end{array}$ & $4,106.0$ & $3,083.1$ & $2,982.2$ & $2,317.7$ & $2,192.5$ \\
\hline 1.1. Linear rehabilitation of banks & $4,106.0$ & $3,007.9$ & $2,419.9$ & $1,789.9$ & $1,614.0$ \\
\hline 1.2. Individual rehabilitation of banks & 0.0 & 0.0 & 473.7 & 405.8 & 484.2 \\
\hline 1.3. Other domestic debt & 0.0 & 75.2 & 88.6 & 122.0 & 94.2 \\
\hline $\begin{array}{l}\text { 2. Foreign debt of the central } \\
\text { government* }\end{array}$ & 149.7 & $1,085.3$ & $2,557.3$ & $3,065.6$ & $3,444.8$ \\
\hline 2.1. Of which: Series A and B bonds** & 0.0 & 0.0 & $1,464.2$ & 1.428 .4 & $1,404.6$ \\
\hline $\begin{array}{l}\text { 3. Total debt of the central government } \\
(1+2)\end{array}$ & $4,255.7$ & $4,168.4$ & $5,539.5$ & $5,383.3$ & $5,637.3$ \\
\hline $\begin{array}{l}\text { 4. Bank liabilities to the Republic of } \\
\text { Croatia** }\end{array}$ & 0.0 & 0.0 & 760.5 & 652.8 & 666.9 \\
\hline $\begin{array}{l}\text { 5. Debt due to bank rehabilitation } \\
(1.1+1.2+2.1-4)\end{array}$ & $4,106.0$ & $3,007.9$ & $3,597.3$ & $2,971.3$ & $2,836.0$ \\
\hline 6. Gross domestic product (GDP) & $18,180.4$ & $18,811.1$ & $19,871.1$ & $19,946.5$ & $21,320.2$ \\
\hline $\begin{array}{l}\text { 7. Share of rehabilitation in the total } \\
\operatorname{debt}(5 / 3 \text { in } \%)\end{array}$ & 96.5 & 72.2 & 64.9 & 55.2 & 50.3 \\
\hline 8. Share of total debt in GDP (3/6 in $\%)$ & 23.4 & 22.2 & 27.9 & 27.0 & 26.4 \\
\hline
\end{tabular}

* Estimate for 1995

** By issuing these bonds, the government assumed certain foreign obligations of the banks. 


\section{Sources: $\quad$ Bulletin of the Croatian National Bank \\ Monthly Statistical Review of the Ministry of Finance \\ Monthly Statistical Review of the State Bureau of Statistics}

The repayment of debts for the rehabilitation of banks was an exceptionally great burden for the national budget, particularly in the period up to 1997. Until the regularization of the repayment of foreign debts (the Paris Club Agreement in 1996 and the London Club Agreement in 1997) and until Croatia received an investment grade, opportunities for larger foreign borrowing were limited. Also, the possibilities for the refinancing of debt in the country, due to the economic consequences of the war, the dissolution of the former Yugoslavia and the loss of the market in the former USSR, were made difficult.

\section{Possible Proportions of New Banking Crises}

New fiscal expenditures for the solving of bank crises, measured by expenditures for the settlement of insured savings deposits in bankrupt banks, are officially estimated at approximately 3 percent of GDP. The question is posed whether this estimate is precise or whether the expenditures will increase due to the potential problems of other banks. In answering this question, it is useful to mention some problems and risks in banking operations.

\subsection{Entwining of Exchange and Credit Risks}

In Croatia there is a regulation on the exposure of banks to total currency risk, which was passed in 1993 and has not been changed since. The exposure of banks to currency risk is measured by the total foreign currency position, which must not exceed 30 percent of the regulatory capital. Banks have greater foreign currency liabilities than foreign currency claims and cannot close the foreign currency position by approving foreign currency credits to the domestic sectors because this is forbidden by law. Therefore, compliance with the regulations on currency risk is achieved by banks through approval of kuna credits with a foreign currency clause. These credits are entered in the balance sheet as kuna assets and not as foreign currency assets.

The netting of the balance sheet foreign currency items (excluding the items in kuna indexed to foreign currency) indicate that banks have short net foreign currency assets (greater foreign currency liabilities than foreign currency claims). The maximum exposure of banks can be 
estimated in an amount of 30 percent of the capital accounts of the banks. ${ }^{24}$ The difference between the net foreign currency assets and 30 percent of the capital accounts is the amount of net kuna assets indexed to foreign currency, which is the minimum necessary in order for a bank to be in compliance with the stipulations on the exposure to currency risk. The amount is enormous the net foreign currency assets of the banks are approximately 6 times greater than the stipulated upper limit of exposure to currency risk.

Table 5. Ratio of net foreign currency assets to the limit of exposure to currency risk, end of period and in million kuna

\begin{tabular}{|l|c|c|c|}
\hline & $\begin{array}{c}\text { Net foreign currency } \\
\text { assets }\end{array}$ & $\begin{array}{c}\text { Capital accounts } \\
(30 \%)\end{array}$ & Quotient \\
\hline 1997 & $-28,581.8$ & $4,989.0$ & 5.7 \\
\hline 1998 & $-35,049.1$ & $5,790.6$ & 6.1 \\
\hline
\end{tabular}

Source: CNB Bulletin

Credits in kuna indexed to foreign currency clause are approved in the first place for the domestic sectors. The trends of the total credits by banks during the past five years are shown in the table below and indicate that the strongest growth in credits was recorded in the household sector. This concerns a sector that does not earn export income and is itself exposed to currency risk.

Table 6. Distribution of banks' credits, end of period and in percentage

\begin{tabular}{|l|r|r|r|r|r|r|r|r|}
\hline & $12 / 93$ & $12 / 94$ & $12 / 95$ & $11 / 96$ & $12 / 96$ & $12 / 97$ & $12 / 98$ \\
\hline Rate of growth in comparison to the end of the previous year (\%) \\
\hline 1. Enterprises & & 29.4 & 16.7 & 14.2 & $-3.1 *$ & 31.6 & 15.9 \\
\hline 2. Household & & 77.4 & 33.7 & 33.3 & 40.7 & 94.2 & 38.2 \\
\hline 3. Other & & 449.6 & 36.1 & 13.2 & 15.9 & 92.8 & 62.5 \\
\hline 4. Total credits (1+2+3) & & 34.6 & 18.9 & 16.8 & 3.1 & 44.1 & 22.2 \\
\hline Structure of credits (\%) & & & & & & & \\
\hline 1. Enterprises & 90.4 & 86.9 & 85.2 & 83.3 & 80.1 & 73.1 & 69.4 \\
\hline 2. Household & 9.4 & 12.4 & 13.9 & 15.9 & 19.0 & 25.6 & 28.9 \\
\hline 3. Other & 0.2 & 0.7 & 0.9 & 0.8 & 1.0 & 1.3 & 1.7 \\
\hline 4. Total credits (1+2+3) & 100.0 & 100.0 & 100.0 & 100.0 & 100.0 & 100.0 & 100.0 \\
\hline
\end{tabular}

${ }^{*}$ Effect of the rehabilitation of Privredna Banka, Zagreb

Source: CNB Bulletin

\footnotetext{
${ }^{24}$ Such an estimate is an overestimate of the actual amount. Regulatory capital consists of Tier I capital and Tier II capital, and capital accounts of Tier I capital and specific reserves for identified losses. The specific
} 
Under such circumstances, the currency and credit risks become entwined because eventual depreciation of the kuna exchange rate can cause an increase in the irrecoverability of credits and the transformation of good credits into bad.

\subsection{Investments in Enterprise Shares}

Investments in enterprise shares, except for several enterprises whose shares are quoted on the stock exchange, are part of the bad assets of banks. These investments occurred primarily through the debt-equity swaps. The swap is generally is performed at the nominal value - the nominal value of the overdue interest and loan principal for the nominal value of the share. The banks cannot sell the majority of these shares.

The percentage of shares in total credits has been reduced since the end of 1994. The following factors can affect the reduction of the percentage: (1) the formation of reserves, i.e. the reporting of the value of the shares according to a value that is less than the nominal value and (2) greater sales of shares than new investments in shares.

Table 7. Banks' investments in enterprise shares, end of period, in million kuna and in percentage

\begin{tabular}{|l|r|l|l|l|l|l|l|}
\hline & $12 / 93$ & $12 / 94$ & $12 / 95$ & $11 / 96$ & $12 / 96$ & $12 / 97$ & $12 / 98$ \\
\hline $\begin{array}{c}\text { 1. Total credits to } \\
\text { enterprises }\end{array}$ & $18,348.2$ & $23,733.5$ & $27,686.4$ & $31,606.3$ & $26,814.7$ & 35.282 .8 & $40,889.4$ \\
\hline 2. Shares & $2,478.5$ & $5,263.2$ & $5,227.0$ & $5,578.5$ & $3,770.9$ & $4,083.7$ & $4,437.7$ \\
\hline $\begin{array}{c}\text { 3.Percentage of } \\
\text { shares in total } \\
\text { credits }\end{array}$ & 13.5 & 22.2 & 18.9 & 17.7 & 14.1 & 11.6 & 10.9 \\
\hline
\end{tabular}

Source: CNB Bulletin

\subsection{Maturity-Gapping of Assets and Liabilities}

The maturity-gapping of assets and liabilities is a normal characteristic of banking operations. In order to stabilize their liquidity, banks keep part of their assets in the form of free reserves with the central bank and in the form of assets that can be easily converted into free reserves.

Bank liabilities consist of liabilities payable on demand and liabilities with a contractual maturity. The largest group of liabilities with a contractual maturity refers to time deposits. Among 
deposits, household foreign currency deposits prevail, which comprise approximately 40 percent of the total liabilities. The second largest source is foreign borrowings, primarily accessible to large banks that have a reputation in foreign countries.

Medium-sized and small banks compete for deposits by offering high interest rates but also other benefits. A very frequent benefit is the possibility to withdraw the deposit prior to the maturity. This benefit fogs the actual maturity of bank liabilities and increases the maturity-gapping of assets and liabilities. Since this primarily concerns foreign currency deposits, in the event of a liquidity crisis the banks require not only kuna liquidity but also foreign currency liquidity.

\subsection{Discrepancy between the Accessibility of Information about Banks and the Application of Regulations}

There is very little public data on the operations of individual banks. The banks are only required to publish an audited annual financial report. This report is published no later than the end of the first half of the following year and the information on the dynamic market environment is relatively out of date. Adequate information on banks cannot even be acquired by banks about their correspondent banks, and other clients can do much less. This lack of information culminated in May 1998 with the collapse of the interbank money market.

The lack of information should not be a serious problem for a highly regulated banking system such as that in Croatia. The Banking Law contains strict stipulations on the supervision by the Croatian National Bank over commercial banks, internal control and the auditing of banks. There is also a system for insuring deposits. Such regulation contributes to the creation of the impression that the probability of losing property due to banking problems is relatively low. The stronger the regulations, the less need is perceived for information about banking operations.

The discrepancy between the information on bank operations and the regulations is a consequence of the problem concerning the application of the legal stipulations on supervision. This problem can be illustrated with the example of the permitted level of exposure in relation to a client or bank shareholder. This level is established by the Banking Law. In the concept one client or shareholder, all the mutually connected persons are included. For example, the exposure to one enterprise is measured as the exposure to all the enterprises that are within the same group of connected enterprises. The poor application of these legal stipulations is due to the following:

a) lack of data on the ownership structure of an enterprise 
Numerous enterprises attempt to conceal data about their ownership structure. The court registries are out of date, and in them the banks cannot verify the ownership structures of their clients.

b) inherited exceeding of the permitted level of exposure

The permitted level of exposure for a client or bank shareholder was introduced in 1989. Until then, the banks chiefly provided credit to "their" enterprises, i.e. bank shareholders. Banks that have operated for many years and whose ownership structures have not changed significantly have inherited this problem.

c) misunderstanding of banking

The linear rehabilitation of banks made it possible for banks to operate according their old ways and to continue the practice of many years of granting credit to shareholders and related persons. Some new banks have adopted this practice, which is evident in the example of the banks in bankruptcy.

\subsection{The Influence of Politicians on Banks}

Until 1991, the banks were under the powerful influence of the political structure. After this, the establishment of many new private banks occurred. Politicians should have a relatively small influence on these banks. The central government has become the owner of four large rehabilitated banks and intends to privatize them. Local political structures have publicly opposed the privatization of some of these banks. This suggests that the influence of the political structures upon banks still exist, although it is less than before.

\section{Conclusion}

The solution of the new banking crisis began with changes in the monetary policy (approval of additional central bank credits to banks) and the initiation of bankruptcy proceedings for certain banks. However, the stated problems and risks of banking operations indicate that some other banks could have similar difficulties and there is no guarantee that the crisis is over. The problems of such banks should be resolved before they stop meeting their obligations in an orderly manner. In solving the problems, exclusive measures are not necessary but it would be worthwhile to use all the available measures. The solving of the problems could result in new fiscal expenditures. 
Both the bankruptcy and rehabilitation of banks result in direct fiscal expenditures. The fiscal expenditures of bankruptcy consist of the costs of paying off insured savings deposits, and fiscal expenditures of rehabilitation include the expenditures necessary for the recapitalization of banks. Since insurance covers a very great part of bank liabilities - in the banks in bankruptcy insurance covers approximately 80 percent of all the savings deposits (public statement issued by the Croatian National Bank, March 24, 1999) — from the standpoint of the amount of fiscal expenditures, there is not a significant difference between bankruptcy and rehabilitation. However, there are differences in the effects of bankruptcy and rehabilitation.

- $\quad$ Bankruptcy can result in the loss of property by some of the bank creditors, and consequently make depositors sensitive to the financial position of banks and lead to a prompt increase in the financial volatility.

- Rehabilitation guarantees the return of property to all the bank creditors and makes depositors more ready to invest in bad banks and leads to the prompt stabilization of financial trends.

The resolution of the new banking crisis with the aid of bankruptcy caused a large redistribution of deposits. A lack of available information made it possible for both good and bad banks to achieve an infow of deposits. It would be necessary to prevent bad banks from continuing their former practices. 


\section{REFERENCES:}

Babić, M., Jurković, P. and Šonje, V. (1999), Banking System Development in Croatia, Zagreb, Journal of Economics, No. 3. pp. 75-113.

Dziobek, C. and Pazarbasioglu, C. (1997), Lessons from Systemic Bank Restructuring: A Survey of 24 Countries, IMF Working Paper, WP/97/161, December.

Frecaut, O. and Sidgwick, V. (1998), Systemic Bank Distress: The Need for an Enhanced Monetary Survey, IMF Paper on Policy Analysis and Assessment PPAA/98/9, August.

Garcia-Herrero, A. (1997), Monetary Impact of a Banking Crisis and the Conduct of Monetary Policy, IMF Working Paper WP/97/124, September.

Garcia, G. (1996), Deposit Insurance: Obtaining the Benefits and Avoiding Pitfalls, IMF Working Paper WP/96/83, August.

Goldstein, M. and Turner, P. (1996), Banking Crises in Emerging Economies: Origins and Policy Options, BIS Economic Papers, August.

Kraft, E. (1999), Croatia's Second Banking Crisis, in manuscript. 